\title{
Information asymmetry, government ownership, and dividends from the building construction from Indonesia
}

\author{
Musdalifah Azis *A; Siti Amalia A; Dio Caisar Darma ${ }^{\text {B }}$ \\ A Mulawarman University, Samarinda City, Indonesia (75117) \\ B Sekolah Tinggi Ilmu Ekonomi Samarinda University, Samarinda (75242) Indonesia
}

Received: December 02, 2020 | Revised: December 6, 2020 | Accepted: December 31, 2020

JEL Classification: G32, G35, D82, E42

DOI: $10.33445 /$ sds.2020.10.6.1

\begin{abstract}
This study investigated to examine the relationship between information asymmetry and government ownership to dividend policy. Information asymmetry is measured using bid-ask spreads, while government ownership is measured using the number of government shares divided by the number of outstanding shares multiplied by $100 \%$. This study uses purposive sampling with a total sample of 9 sub-companies construction and building listed on the Indonesia Stock Exchange (ISE) in 2016-2019. The data used is quantitative data and data sources were taken from the company's annual financial statements. Descriptive statistics and panel data regression are used as data analysis tools. The results showed that information asymmetry has a positive and significant effect on dividend policy, government ownership does not have a significant negative effect on dividend policy, and the interaction of information asymmetry and government ownership moderates the dividend policy.
\end{abstract}

Key words: dividend, information asymmetry, government ownership, construction building sub-sector.

\section{Introduction}

The main objective of the establishment of the company grows welfare shareholders which can be increased through policy dividends. Dividend profit policy is obtained company and given to the shareholders or kept as profit detained who is employed to manage the activity of the operating company. Dividend to given to shareholders and will act as a signal to investors (Mirza, 2014).

Sub the construction sector buildings as object research increased value continue to rise and continued to grow in Indonesia. One of the causes because of the high demand for housing and high sector property in Indonesia (Darma et al., 2015). At 2019, Investors recommending shares issuers working on construction project infrastructure government. But, stock prices rise sub-construction sector more complicated. So that if in the future, asymmetry concerns information and influence the dividend.

The dividend which is not optimal will cause asymmetry information against the company and shareholders. Many things that can be associated with the low performance, dividends one of them is investors hesitate to back their investment to the company. The application of asymmetry information can help a company problem in providing information to the company to increase profit. So the company can increase the number of investors and companies can get more financial resources (Li \& Zhao, 2008). Althought, Alfaraih et al. (2012) and Lee et al. (2020) concluded there is a positive connection between the asymmetry information policy of dividends.

The government possession charge negatively influences dividend distribution, because with the government then, a

\footnotetext{
* Corresponding author: Lecturer, Department of Management, e-mail: musdalifah.azis@feb.unmul.ac.id, ORCID: 0000-0003-1627-2513
} 
possession charges the dividends given to the smaller. But, on the theory up following the data researchers gain from the company financial report sub-sector the construction site (Lin et al., 2016). In 2016, dividend which obtained the company which is the ownership of the government and to the company $0 \%$ total which is the company is not the government ownership 69.34\%. But in 2017, dividends increased namely $19.94 \%$ while in the company total is $73.72 \%$ also rose. This is consistent with the theory on the existence of a negative relationship between the rich dividends. government against its policies. But the research from Mehdi \& Neda (2014) shows positive results against the government in the dividend and possession of a relationship.

Based on the phenomena and some issues related to this matter, it is interesting for us to invest the influence of information asymmetry and government ownership on dividends from the building construction in Indonesia. Contributions resulting from this study are expected to be a reference material and policies from various groups.

\section{Material and methods}

Literature Review. The act of the company management guidance to investors see about management still is in a company (Brigham \& Houston, 2003; Mirza, 2014). The prospect of this company was a condition that will be faced by the company at a time to come (Akhigbe et al., 1993). The depiction of treatment behaviour when the individual or corporation have access to different information (Brian et al., 2010). A policy change dividends useful to convey information about change cash flows will come to the manager (Dionne \& Ouederni, 2009).

Agency theories describing on a phenomenon dissimilarity of interests between those and agent, which states that each interest of each act on each side (Jensen \& Meckling, 1976; Moh'd et al., 1995; Mancinelli \& Ozkan, 2006). Because different purposes each of side trying to obtain greater advantage (Kathleen, 1989). A dividend can be used to get the agency in the company free cash flow by reducing and asked management to provide funding on the capital market so that it can monitor off (Ritter \&Warr, 202). The payment of dividends agency because the potential to decrease the amount of finance larger allows external more effective than in the company internal financial. The dividend is the division of net profit of between the owner of stock based on several which is controlled (Al-Najjar \& Kilincarslan, 2016; Khang \&King, 2002).

The division will reduce the total cash held there with profit for the company, but the earnings share to the owners share is the main objective of a particular business. Dividends can also be used holders controlling shares to compensate concerns minority shareholders in the neighbourhood enterprise in which a takeover profit by the shareholders' control applies. The dividends were dependent on susceptibility to a takeover shareholder, measured use dividends per net profit (Alamdari, 2016; Al-Shubiri et al., 2012; Mancinelli \& Ozkan, 2006).

Asymmetry information, secret information between the balance management information and shareholders the users having an interest is information (Lin et al., 2017). Asymmetry company information as a standard deviation error, the analyst profit by is measured using relative bid-ask spread operated:

$\operatorname{SPREAD}_{i, t}=\left(\right.$ ask $\left._{i, t}-\operatorname{bid}_{i, t}\right) /\left\{\right.$ ask $_{i, t}+$ bid $\left.\left._{i, t}\right) / 2\right\} \cdot 100$

The measurement of the estimated profit by at least two analysts in every company, when the estimated income analyst for the company for years that is more widespread, the information will be more uncertain. Asymmetry information emerged when one has more knowledge about risk, the transaction or contracts with people or anyone else (Sahar \& Mayahi, 2014).

Ownership of the government is many a share of part a company that have by the government (Farooque et al., 2007). Stock 
ownership of the companies of state commonly countries to have gone public. It is important to consider the ownership structure of the government to develop emerging markets who understand the dividend policy related to the agency in the market (Ben-Nasr, 2015). The government ownership is measured using the percentage of the government stock divided by the number of shares outstanding The government ownership is measured using the percentage of the government stock divided by the number of shares outstanding (Nguyen \& Vo, 2020).

Methodology. This study uses descriptive statistic regression data panel Eviews 10 as the analysis. The model used in this study are:

$$
D I V=\alpha_{1}+\beta_{1} A S Y+\beta_{2} S O+\beta_{3} I N T+e
$$

where: DIV (Investments Efficiency), $\alpha_{1}$ (Constanta), $b_{1} \quad \ldots . \quad b_{4}$ (Coefficients), ASY (Assimetric Information), SO (Government Ownership), INT (Interaction variabel between Assimetric Information and Government Ownership), and e (error term).

The population of this research is all company's sub-construction sector buildings listed at the Indonesian stock exchange 20162019 period that began. The size of the sample population in this study is 14 manufacturing firm building construction sub-sector. In the study is used techniques purposive sampling techniques which this technique was the sample with a certain consideration. The kind of data that used inside this research is quantitative data. The data derived from this study of secondary data (Yahya \& Wahyuningsih, 2020).

\section{Results and discussion}

On the model FEM the value of the coefficients determined $\left(R^{2}\right) 0.905471$. As much as that means the dependent variable (DIV) $90,54 \%$ can be influenced as much as by the independent variable (ASY, OWN, and INT). Interaction the remaining $9,46 \%$ described by other variables that not contained in this research. Model. The test results regression panel data showing that the statistics as much as 7.1085. $F$ with the value of the significance same that is as much as 0.0019 is smaller than 0.05 $(0.000<0.05)$. These results explain that three of the independent variable namely, temple own, and INT simultaneously influential simultaneous against div on subsector company construction and building a sample BEI 20162019 period and have shown a model worth.

Test of variable ASY (X1) having value t value is 1.720481 and the level of probability is 0.033 $<0.05$. Testing shows the researchers ASY is 0.1706 to DIV with the significance of $0.033<$ 0.05 and partial regression in and models in this research and significantly to have had a positive impact DIV (hypothesis 1 accept).

Table 1 - The regression analysis data panel

\begin{tabular}{lccccc}
\hline & $\begin{array}{c}\text { Coefficient } \\
\text { Regression }\end{array}$ & t-value & Prob. & Direction & Conclusion \\
\hline Constanta & 81.08189 & 0.271603 & 0.7883 & & \\
ASY & 0.170649 & 1.720481 & 0.0033 & + & Significant \\
OWN & -1.620463 & -0.502742 & 0.6915 & - & Not significant \\
INT & -0.005241 & -0.630018 & 0.4729 & - & Not significant \\
R-Square $=0.905471$ & & & & \\
Adjust R-Square $=0.714226$ & & & & \\
F-value $=7.1085$ & & & & \\
F Prob. $=0.000019$ & & & & \\
\hline
\end{tabular}

Source: author calculations 
Variable OWN (X2) having value $t$ value is 0.502742 and the level of probability is $0.6915>$ 0.05 . Testing shows the researchers $\mathrm{OWN}$ is 1.620463 to DIV with significant of $0.6915>0.05$ and models in the partial regression was influential negative significantly to DIV (hypothesis 2 not accept). Variable INT (X3) having value $t$ value is -0.630018 and the level of probability is $0.4729>0.05$. Testing shows the researchers INT is -0.005241 to dividend with the significance of $0.4729>0.05$ and models in

$$
D I V=81.08189+0.170649 A S Y-2 .
$$

This research found that asymmetry information had a positive impact and significant impact on dividends. This result in line with a hypothesis that stated that asymmetry information significant to the payment of dividends. The result of this research was not in line with Li \& Zhao (2008), see that asymmetry information have a negative influence with the payment of the dividend, that does not conform to signify hypothesis.

The research indicated that asymmetry information has had a positive impact on significant means hypothesis 1 accepted. There are several reasons, because when the company receive asymmetry information higher so level dividends received more firm greater than shareholders. It can cause the have dividends greater. But, the company expected to reduce asymmetry information. It is meant to shareholders have the true information.

Government ownership has a negative influence not significantly to dividends. Means if the company state-owned so dividends or company decrease. The ownership of the government has a negative influence on the amount of the dividend because with the government ownership so, dividends given getting smaller (Tahir et al., 2020; Lin et al., 2017).

The empirical findings found that the government ownership influential negative significantly to a dividend means hypothesis 2 rejected. Show rejected a hypothesis is if the government companies so or is less than not governmental ownership. The impact of and if the partial regression was influential negative significantly to DIV (hypothesis 3 not accept) with the significance of $5 \%$.

The results of the study found variable ASY significant and interaction ASY with own also found significant. So, can be concluded that variable ASY is the variable moderation to a category moderation specious. Based on the testing regression in Table 1 shown so a model of research is:

\section{$2.3226140 W N-0.005241 / N T+e$}

the company of government ownership of the dividends received more firm so little. So, if want to get more dividend company can reduce planting stockholders of government. This is government ownership to reduce company dividends.

Anderson et al. (2009) show that control company shareholders may limit the company to reduce transparency. Brevity, of government ownership of the asymmetry associated positive for information. This study thought that firms the countries will have higher agency asymmetry information higher. Moreover, extracting some tending to personal benefits through the payment of dividends.

This study result indicates that information and interaction asymmetry of government ownership of the influential negative significantly to a dividend means hypothesis to 3 rejected. This indicates that asymmetry information and will not affect dividends of government ownership of the company. The reason why this hypothesis rejected because it, essentially firm that has the asymmetry information tending to have a dividend higher and company tending to have a dividend of government ownership of the lower. So, when variables asymmetry information and ownership variables interaction hence indicating the negative and not significant. Therefore, government ownership of the company will increase to urged profit to companies building the sub-construction sector to obtain a dividend higher. 


\section{Conclusions}

Asymmetry has had a positive impact significantly to information to companies and the subsector construction buildings listed at ISE. The is based on the previous study. Where the higher asymmetry information a company hence the higher the dividends to be obtained. Further research shows that government has influential negative and not significant to dividends. Results in line with a hypothesis advanced before where government so when a corporation owned a dividend will be fewer obtained investors. Interaction asymmetry information and of government ownership of the influential negative significantly to dividends. This indicates that the hypothesis is not under the previous study which asymmetry information and interaction of government ownership of the to dividends have had a positive impact.

Companies should reduce asymmetry information by doing dividend disclosure information on to the party that requires that the parties require can use of information was make decisions like investors when it comes to investing into the company. By the decrease asymmetry information, so the dividend will be inflated as with asymmetry information high makes the investors difficulty in making decisions for lack of the information obtained. Shares of a company owned the government should have the dividend higher. That between companies and government have the advantage the same. A company that owns asymmetry information and is owned the government should have a dividend larger. This could affect financial companies and attract investors.

\section{References}

Akhigbe, A., Borde, S. F., \& Madura, J. (1993). Dividend Policy and Signaling by Insurance Companies. Journal of Risk and Insurance, 6O(3), 413-428. DOI: 10.2307/ 253036

Al-Najjar, B., \& Kilincarslan, E. (2016). The effect of ownership structure on dividend policy: Evidence from Turkey. Corporate Governance, 16(1), 135-161. DOI: 10.1108/CG-09-20150129

Al-Shubiri, F. N., Al-Taleb, G., Al-Naser, A., \& AlZoued, A. N. (2012). The Relationship between Ownership Structure and Dividend Policy: An Empirical Investigation. Review of International Comparative Management, 13(4), 644-658.

Alamdari, N. N. (2016). Relationship Between Information Asymmetry and Dividend Policy of Companies Listed in TSE. IJABER, 14(10), 70477057.

Alfaraih, M., Alanezi, F., \& Almujamed, H. (2012). The Influence of Institutional and Government Ownership on Firm Performance: Evidence from Kuwait. International Business Research, 5(10), 192-200. DOI: 10.5539/ ibr.v5n10p192

Anderson, R. C., Duru, A., \& Reeb, D. M. (2009). Founders, heirs, and corporate opacity in the United States. Journal of Financial Economics, 92(2), 205-222. DOI: 10.1016/j.jfineco.2008.

\subsection{6}

Ben-Nasr, H. (2015). Government Ownership and Dividend Policy: Evidence from Newly Privatised Firms. Journal of Business Finance and Accounting, 42(5-6), 665-704. DOI: 10.1111/jbfa.12115

Byun, H. Y., Hwang, L. S., \& Lee, W. J. (2011). How does ownership concentration exacerbate information asymmetry among equity investors?. Pacific Basin Finance Journal, 19(5), 511-534.

https://doi.org/10.1016/j.pacfin.2011.06.002

Chen, L. L., \& Wang, A. M. L. (2012). International evidence on industrial diversification and asymmetric information across different ownership structures. Asia Pacific Management Review, 17(1), 37-76.

Connelly, B. L., Certo, S. T., Ireland, R. D., \& Reutzel, C. R. (2011). Signaling Theory: A Review and Assessment. Journal of Management, 37(1), 39-67. DOI: 10.1177/0149206310 388419

Dionne, G., \& Ouederni, K. (2009). Corporate Risk Management and Dividend Signaling Theory. Finance Research Letters, 8(1008), 1-9. DOI: 10.2139/ssrn.1545845 .

Darma, D. C., Haryadi, H., \& Umiyati, E. (2015). Potensi Sektor Perekonomian di Kabupaten 
Malinau Provinsi Kalimantan Utara. Jurnal Perspektif Pembiayaan dan Pembangunan Daerah, 2(4), 173-180.

Farooque, O., Zijl, T., Dunstan, K., \& Karim, A. (2007). Corporate Governance in Bangladesh: Link between Ownership and Financial Performance. Journal Compilation, 15(6), 1453-1468. DOI: 10.1111/j.1467-8683.2007. 006 57.x

Kathleen, M. E. (1989). Agency Theory: An Assessment and Review. Academy of Management Review, 14(1), 57-74. https://doi.org/10.5465/amr.1989.4279003

Khang, K., \& King, D. (2002). Is Dividend Policy Related to Information Asymmetry: Evidence from Insider Trading Gains. AFA 2003 Washington, DC Meetings. DOI: 10.2139/ssrn.342621

Lee, J., Lee, S. J., Choi, S., \& Kim, S. (2020). The Usefulness of Other Comprehensive Income for Predicting Future Earnings. Journal of Asian Finance, Economics and Business, 7(5) 31-40. DOI: 10.13106/jafeb.2020.vol7.no5.031

Li, K., \& Zhao, X. (2008). Asymmetric information and dividend policy. Financial Management, 37(4), 673-694. DOI:10.1111/j.1755-053X. 2008.00030.x

Lin, T. J., Chen, Y. P., \& Tsai, H. F. (2017). The relationship among information asymmetry, dividend policy and ownership structure. Finance Research Letters, 20, 1-12. DOI: 10.1016/j.frl.2016.06.008

Lin, Y. H., Chiou, J. R., \& Chen, Y. R. (2010). Ownership Structure and Dividend Preference. Emerging Markets Finance and Trade, 46(1), 56-74. DOI: 10.2753/REE1540-496X46 0106

Mancinelli, L., \& Ozkan, A. (2006). Ownership structure and dividend policy: Evidence from Italian firms. European Journal of Finance, 12(3), 265-282. DOI: 10.1080/135184705 00249365

Mehdi , E. S., \& Neda, M. (2014). Asymmetric Information and Dividend Payout Policy. Indian
Journal of Fundamental and Applied Life Sciences, 4, 30-35.

Mirza, H. M. (2014). Ownership Structure and Dividend Policy: Evidence from South Asia. Available at https://ssrn.com/abstract= 3271864

Moh'd, M. A., Perry, L. G., \& Rimbey, J. N. (1995). An Investigation of the Dynamic Relationship between Agency Theory and Dividend Policy. Financial Review, 30(2), 367-385. DOI: 10.1111/j.1540-6288.1995.tb00 837.x

Nguyen, M. H., \& Vo, Q. T. (2020). Investigating the Association between Residual State Ownership and Privatized Firm Efficiency. Journal of Asian Finance, Economics and Business, 7(5), 225236. DOI: 10.13106/jafeb.2020. vol7.no5.225

Ritter, J., \& Warr, R. (2002). The Decline of Inflation and the Bull Market of 1982-1999. Journal of Financial and Quantitative Analysis, 37(1), 2961. DOI: $10.2307 / 3594994$

Sun, Q., Tong, W. H. S., \& Tong, J. (2002). How Does Government Ownership Affect Firm Performance? Evidence from China's Privatization Experience. Journal of Business Finance and Accounting, 29(1\&2), 1-27. DOI: 10.1111/1468-5957.00422

Tahir, H., Rahman, M., \& Masri, R. (2020). Do Board Traits Influence Firms' Dividend Payout Policy? Evidence from Malaysia. Journal of Asian Finance, Economics and Business, 7(3), 87-99. DOI: 10.13106/jafeb.2020. vol7.no3.87 Vojtech, C. M. (2012). The Relationship Between Information Asymmetry and Dividend Policy. FEDS Working Paper No. 2012-13. DOI: 10.2139/ssrn.2051018

Yahya, A., \& Wahyuningsih, D. (2020). Pengaruh Perencanaan dan Aset Pajak Tangguhan Terhadap Manajemen Laba Pada Perusahaan Telekomunikasi dan Konstruksi yang Terdaftar di Bursa Efek Indonesia Periode 2013-2017. Sosiohumanitas, 21(2), 86-92. DOI: 10.36555/sosiohumanitas.v21i2.1242 